\title{
Manufacture of dahi from skim milk adding mango juice
}

\author{
MA Kabir* ${ }^{1}$, MH Rashid ${ }^{2}$, MN Hassan ${ }^{2}$, MF Afroz $^{1}$, FH Miraz ${ }^{1}$ \\ ${ }^{1}$ Bangladesh Livestock Research Institute, Savar, Dhaka; ${ }^{2}$ Department of Dairy Science, Bangladesh \\ Agricultural University, Mymensingh 2202, Bangladesh
}

\begin{abstract}
The aim of this research was to prepare and evaluate the quality of dahi using skim milk fortified with 5 , 10 and 15 percent of mango juice. The quality of prepared dahi was measured by organolaptic, chemical and microbiological tests. Significant difference was observed within the smell and taste score $(p<0.05)$, the body and consistency score $(p<0.01)$ and color and texture $(p<0.05)$ of different types of dahi. Fat, ash and total solids content differed significantly $(p<0.05)$ among the different types of dahi with mango juice but protein content and $\mathrm{pH}$ values did not differ significantly $(\mathrm{p}>0.05)$ among the different types of dahi with mango juice. There was no significant difference $(p>0.05)$ in case of total viable organisms count but significant difference $(p<0.05)$ was found in case of Coliform count among the different types of dahi with mango juice. From this study it was suggested that dahi could be prepared successfully by adding different proportion of mango juice with skim milk and $10 \%$ mango juice addition showed better result.
\end{abstract}

Key words: Dahi, mango juice, skim milk

Bangladesh Animal Husbandry Association. All rights reserved. Bang. J. Anim. Sci. 2014.43 ( 2): 128-131

\section{I ntroduction}

Dahi is custard like semi solid, acidified dairy product made by fermenting partially evaporated milk with a special culture containing lactic acid producing bacteria (Munzur et al. 2004). Dahi is also known as dahi in western countries. Of all, dahi is the most popular and oldest fermented milk product for human being all over the world (Mansour et al. 1994). Fermentation has been an ideal technology to preserve milk from time immemorial. Like milk, dahi is a healthy and delicious food due to its high nutritive and therapeutic value (Perdigon et al. 2002). Due to low lactose content dahi is easily digestible and palatable than milk. Dahi is valued for controlling the growth of bacteria and in curing of intestinal disease like constipation, diarrhea and dysentery, anti-carcinogenic effect and lowering of blood cholesterol (Kamruzzaman et al. 2002). Flavour, texture and aroma of dahi depend upon the country of origin as well as other factors including raw materials quality, manufacturing process and the strains involved (Kumar and Mishra 2004). Dahi is generally considered as a safer product and its unique flavor appeals to so many that consideration is being given by nutritionists to incorporate inexpensive source of nutrients to make it an almost complete food (Boghra and
Mathur 2000). Preparation of fruit dahi has been investigated by a number of researchers in different parts of world (Desai et al. 1994; Shukla et al. 1987). It is generally found that, sweetmeat makers usually withdraw some portion of fat from milk and use the remaining low quality milk fat dahi making and they sell it to the consumers mentioning as whole milk or full fat milk dahi. As a result, consumers are not getting quality products. Nowadays, dahi prepared from skim milk has got much popularity throughout the world as it does not contain fat which could be notorious to human body sometimes. Skim milk fruit dahi can be prepared by adding different type of fruits to skim milk. Fruits addition makes the skim milk dahi colored, attractive and more nutritive. Mango is one of highly and tasty fruits with a high nutritive value which might be added to skim milk to prepare dahi (Mondal and Amin 1990). From these concepts, this research was conducted to prepare and evaluate the quality of dahi using mango juice at different levels.

\section{Materials and Methods}

The experiment was conducted in the laboratory of the Department of Dairy Science in collaboration with Department of Food 
Technology and Rural Industries, Bangladesh Agricultural University, Mymensingh, during the period from 01 July to 31 October, 2012. Fresh whole milk was collected from Dairy farm of Bangladesh Agricultural University, Mymensingh. The collected whole milk was skimmed by an electric cream separator. Fruits, sugar and starter culture collected from local market. Ripened mangoes (Mangifera indica) were washed with clean water and skin was separated with the help of knife aseptically. The seeds were removed and mango pulps were blended. After blending, the juice was filtered with clean cloth (hot water washed). These were kept in plastic containers and stored at freezing temperature $\left(-20^{\circ} \mathrm{C}\right)$ until preparation of dahi.

Skim milk was heated to reduce about one-fourth of its original volume and sugar was added at the rate of $12 \%$ during boiling. During heating, milk was stirred continuously with the help of a stirrer. After desired heating, milk pan was taken out from the heater and allowed to cool. When the temperature was about $40^{\circ} \mathrm{C}$, then milk was divided into four equal portions namely $A, B, C$ and $D$ and different types of dahi was prepared from each portion. Sample A was maintained as control group. The mango juice which was previously prepared was incorporated into dahi at 5, 10 and 15\% level. Milk was inoculated with desirable proportion of starter culture (2\%) which was collected from local market. The plastic cups were pre-washed with boiled water before using. The samples were incubated at $42^{\circ} \mathrm{C}$ until the complete coagulation of dahi (7-8 hrs). The dahi samples were stored at about $4^{\circ} \mathrm{C}$ at refrigeration until judging.

After complete curd formation, the samples were judged separately by a team of experienced judges for organoleptic parameters including smell and taste, body and consistency, color and texture and data were analysed statistically. Total solids (TS) and ash content of the different type of milk and juice samples were determined according to AOAC (2002). Fat percent was determined by Babcock method (Aggarwala and Sharma, 1961). Crude protein was determined by Kjeldahl (Ranganna 1979) procedure. $\mathrm{pH}$ was measured with the help of a pH meter (HANNA instruments, $\mathrm{HI}$ 8424, microcomputer $\mathrm{pH}$ meter). Acidity was determined by titration with $0.1 \mathrm{~N}$ $\mathrm{NaOH}$ solutions using the procedure by Aggarwala and Sharma (1961).
Prepared dahi samples were examined for total viable count and total coliform count. For total viable count of bacteria, colony count method was used according to laboratory methods in Food Microbiology (Harrigan 1998). The total number of viable bacteria per gram of dahi was obtained by multiplying the number of colony forming units (CFU) on the plate with respective dilution factor and then was converted into logarithmic form. Total coliform (MPN g-1) was counted by most probable number (MPN) method. Analysis was performed by employing statistical package for social science (SPSS version 17.0) software and Completely Randomized Design for the statistical analysis of this study. To compare mean values between groups t-test was done as a test of significance.

\section{Results and Discussion}

Plain dahi (no fruit juice added) was compared with dahi incorporating different concentrations $(5,10$ and $15 \%)$ of mango juices for average smell and taste, body and consistency and color and texture by a team of judges. Results of the organoleptic tests were presented in Table 1.

Table 1. Physical characteristics on quality of different types of fruit dahi samples

\begin{tabular}{|c|c|c|c|c|c|}
\hline \multirow{2}{*}{$\begin{array}{l}\text { Physical } \\
\text { characteristics }\end{array}$} & \multicolumn{4}{|c|}{ Types of fruit dahi (Mean \pm SE) } & \multirow{2}{*}{$\begin{array}{l}\text { Sig. } \\
\text { level }\end{array}$} \\
\hline & $A$ & $B$ & $C$ & $D$ & \\
\hline $\begin{array}{l}\text { Smell and } \\
\text { taste }\end{array}$ & $\begin{array}{l}39.11^{\mathrm{a}} \\
\pm 0.91\end{array}$ & $\begin{array}{l}43.89 b \\
\pm 0.63\end{array}$ & $\begin{array}{l}46.56 c \\
\pm 0.41\end{array}$ & $\begin{array}{l}44.67 \mathrm{bc} \\
\pm 0.66\end{array}$ & * \\
\hline $\begin{array}{l}\text { Body and } \\
\text { consistency }\end{array}$ & $\begin{array}{l}26.56^{b} \\
\pm 0.80\end{array}$ & $\begin{array}{l}25.11^{a} \\
\pm 0.01\end{array}$ & $\begin{array}{l}27.56^{b} \\
\pm 0.55\end{array}$ & $\begin{array}{l}24.89 a \\
\pm 0.48\end{array}$ & ** \\
\hline $\begin{array}{l}\text { Colour and } \\
\text { texture }\end{array}$ & $\begin{array}{l}12.00^{\mathrm{a}} \\
\pm 0.50\end{array}$ & $\begin{array}{l}15.00^{\mathrm{bc}} \\
\pm 0.64\end{array}$ & $\begin{array}{l}18.00^{c} \\
\pm 0.00\end{array}$ & $\begin{array}{l}14.67^{\mathrm{b}} \\
\pm 0.52\end{array}$ & * \\
\hline
\end{tabular}

Means with different superscripts in the same row differed significantly $(* *, p<0.01 ; *, p<0.05) ; A$, plain dahi, $B$, skim milk $+5 \%$ mango juice added dahi, C, skim milk $+10 \%$ mango juice added dahi, D, skim milk $+15 \%$ mango juice added dahi

Analysis showed that there was significant difference $(p<0.05)$ within the smell and taste score of different types of dahi. The highest smell and taste score (46.6) was recorded in case of C type dahi (dahi with $10 \%$ mango juice). On the other hand, lowest score (39.1) was seen in case of A type dahi. So, when we want to prepare mango juice dahi with skim milk adding $10 \%$ mango juice give the better smell and taste. Similar results were also reported by Desai et al. 
(1994). They found that smell and taste of dahi was improved due to the addition of $10 \%$ fruit juice. Hossain et al. (2012) found that smell and taste of dahi was optimum level due to the addition of $10 \%$ orange juice which gave the best result.

Analysis showed that there was significant difference $(p<0.01)$ within the body and consistency scores of different types of dahi. Highest body and consistency score were found in case of $C$ type dahi. On the other hand, lowest score was seen in case of D type dahi. It was found that the addition of fruit juice increased the body and consistency score of dahi (Desai et al. 1994,). Optimum body and consistency of dahi was found in dahi with $10 \%$ orange juice (Hossain et al. 2012).

Table 1 also shows that there was significant difference $(p<0.05)$ among the colour and texture of different types of dahi. The highest colour and texture score was recorded in C type dahi. On the other hand, lowest score was seen in case of A type dahi. The result of this experiment indicates that colour and texture of dahi is optimum level due to the addition of $10 \%$ mango juice which gave the best result. The result agrees with the work of Desai et al. (1994) and Hossain et al. (2012), they observed that addition of $10 \%$ fruit juice improved the colour and texture score of dahi. Regarding dahi appearance advocated the use of stabilizers and additives to improve the appearance of dahi (Shukla et al. 1987).

The chemical composition of different types of dahi samples are presented in Table 2. The differences in fat percentage between plain dahi and dahi containing mango juice were significant $(p<0.05)$. Maximum fat percent was seen in plain/control (A) dahi and fat percent was found to gradually decrease in addition of mango juice. Generally fruit contains low level of fat. So, the addition of fruit juice might have decreased the fat percent of fruit dahi (Desai et al. 1994, Hossain et al. 2012).

Analysis showed that the protein content did not differ significantly $(p>0.05)$ among the different types of dahi with mango juice. The protein content was higher in plain dahi and lower in dahi with $15 \%$ mango juice. The protein content was decreased due to addition of fruit juice because fruit juice contains lower protein than milk (Desai et al. 1994; Hossain et al. 2012).

Table 2. Chemical compositions of different types of dahi samples

\begin{tabular}{lcccc}
\hline Chemical & \multicolumn{4}{c}{ Types of dahi (Mean \pm SE) } \\
\cline { 2 - 5 } characteristics & A & B & C & D \\
\hline Fat $(\mathrm{g} / \mathrm{kg})$ & $0.14 \mathrm{a} \pm 0.01$ & $0.09^{\mathrm{b}} \pm 0.00$ & $0.07 \mathrm{~b} \pm 0.00$ & $0.06^{\mathrm{b}} \pm 0.00$ \\
\hline Protein $(\mathrm{g} / \mathrm{kg})$ & $4.25 \pm 0.12$ & $4.11 \pm 0.12$ & $4.03 \pm 0.13$ & $3.98 \pm 0.14$ \\
\hline Ash $(\mathrm{g} / \mathrm{kg})$ & $0.96 \mathrm{c} \pm 0.00$ & $0.95^{\mathrm{b} c} \pm 0.01$ & $0.92^{\mathrm{b}} \pm 0.02$ & $0.87 \mathrm{a} \pm 0.02$ \\
\hline $\mathrm{TS}(\mathrm{g} / \mathrm{kg})$ & $25.49 \mathrm{a} \pm 0.45$ & $28.67^{\mathrm{a}} \pm 1.09$ & $32.16^{\mathrm{bc}} \pm 1.64$ & $36.03^{\mathrm{c}} \pm 1.11$ \\
\hline $\mathrm{pH}$ & $4.74 \pm 0.44$ & $4.63 \pm 0.48$ & $4.59 \pm 0.47$ & $4.54 \pm 0.46$ \\
\hline
\end{tabular}

TS, total solids; means with different superscripts in the same row differed significantly $(p<0.05) ; N S$, non significant; $A$, plain dahi, $B$, skim milk $+5 \%$ mango juice added dahi, $C$, skim milk $+10 \%$ mango juice added dahi, D, skim milk $+15 \%$ mango juice added dahi

Statistical analysis showed that there was significant difference $(p<0.05)$ within the ash content of different types of dahi. The ash content was higher in plain dahi and lower in dahi with $15 \%$ mango juice. Overall ash content of dahi with $15 \%$ mango juice was somewhat lower than that of plain dahi (Desai et al. 1994; Hossain et al. 2012).

Table 2 also shows that there was significant difference $(p<0.05)$ within the total solids content of different types of dahi. The highest value of total solid content was recorded in case of D type (dahi with $15 \%$ mango juice) dahi and the lowest value was recorded in case of A type dahi. This indicated that total solid content increased with addition of mango juice. The addition of fruit juice significantly increased the total solids content of dahi (Hossain et al. 2012).

The differences of $\mathrm{pH}$ values among the samples were statistically insignificant $(p>0.05)$. Fruits are acidic in nature. So adding fruit $\mathrm{pH}$ value of dahi was decline. In this experiment acidity of mango juice fortified dahi increased which might be reason of declining $\mathrm{pH}$ values of dahi. The result of present findings agreed with the work of Ghosh and Rajorhia (1987) who found that acidity content of dahi decreased due to the addition of different level of fruit.

Table 3 shows that there was no significant difference $(p>0.05)$ in term of total viable organisms count among the different types of 
dahi. The highest total viable organism (log CFU $\mathrm{g}^{-1}$ ) was recorded for dahi with $15 \%$ mango juice and lowest value was recorded for plain dahi. This finding indicated that total viable count increased with addition of mango juice (Hossain et al. 2012).

Table 3. Microbiological quality of different types of fruit dahi samples

\begin{tabular}{lcccc}
\hline \multirow{2}{*}{ Parameter } & \multicolumn{5}{c}{ Types of dahi (Mean \pm SE) } \\
\cline { 2 - 5 } & $\mathrm{A}$ & $\mathrm{B}$ & $\mathrm{C}$ & $\mathrm{D}$ \\
\hline $\left.\left.\begin{array}{l}\text { TVC, } \log \\
(\mathrm{CFU} \mathrm{g}\end{array}\right)^{-1}\right)$ & $106.7 \pm 11.66$ & $108.3 \pm 9.38$ & $108.3 \pm 6.17$ & $113.0 \pm 8.02$ \\
\hline $\begin{array}{l}\text { Coliform } \\
\left(\text { MPN g-1 }^{-1}\right)\end{array}$ & $2.3^{\mathrm{a} \pm 0.33}$ & $6.7 \mathrm{~b} \pm 1.45$ & $8.0^{\mathrm{b} \pm 1.52}$ & $9.7 \mathrm{~b} \pm 0.33$ \\
\hline
\end{tabular}

Means with different superscripts in the same row differed significantly $(p<0.05) ; A$, plain dahi, B, skim milk $+5 \%$ mango juice added dahi, $C$, skim milk $+10 \%$ mango juice added dahi, D, skim milk $+15 \%$ mango juice added dahi; TVC, total viable count, CFU, colony forming unit, MPN, most probable number

Result showed that there was significant difference $(p<0.05)$ among the different samples. The highest coliform content was found in $D$ type dahi and the lowest coliform count content was found in A type of dahi. This finding agrees with the findings of Hossain et al. (2012).

\section{Conclusion}

Therefore, it could be recommended that addition of $10 \%$ mango juice with skim milk might be used to prepare high quality mango fruit flavored dahi. So, the manufacturers and the consumers might welcome to incorporation of mango juice in the manufacture of dahi from skim milk.

\section{Reference}

Aggarwala AC, Sharma RM (1961). A Laboratory Manual of Milk Inspection. $4^{\text {th }}$ Edn, Asia Publishing House, New Delhi, India, P. 14

AOAC (2002). Official Methods of Analysis. $17^{\text {th }}$ Edn, Association of Official Analytical Chemists, Gaithersburg, MD, USA.

Boghra VR, Mathur ON (2000). Physico-chemical status of major milk constituents and minerals at various stages of Shrikhand preparation. Journal of Food Science and Technology. 37: 111-115.

Desai SR, Toro VA, Joshi SV (1994). Utilization of different fruit in the manufacture of yogurt. IJDS, 47: 870-874.

Ghosh J, Rojorhia GS (1984). Chemical microbiological and sensory properties of misti Dahi in Calcutta. Asian Journal of Dairy Research, 6: 11-18.

Harrigan WF (1998) Laboratory Methods in Food Microbiology. $3^{\text {rd }}$ Edition, Academic Press Limited, London, UK

Hossain MN, Fakruddin M, Islam MN (2012). Development of Fruit Dahi (Dahi) Fortified with Strawberry, Orange and Grapes Juice. American Journal of Food Technology, 7: 562-570.

Kamruzzaman M, Islam MN, Rahman MM, Parvin S, Rahman MF (2002). Evaporation rate of moisture from dahi (yogurt) during storage at refrigerated condition. Pakistan Journal of Nutrition, 1: 209-211.

Kumar P, Mishra HN (2004). Mango soy fortified set yoghurt. Effect of stabilizer addition on physicochemical, sensory and textural properties. Journal of Food Chemestry, 87: 501-507.

Mansour AA, Khalifa MY, Hanafy NM (1994). Utilization of some dairy by product in yogurt manufacture. Egyptian Journal of Food Science ,22: 87-97.

Mondal MF, MR Amin. 1990. In Bengali: Pholer Bagan (Fruit Orchard). Mrs. Afia Mondal, BAU Campus, Mymensingh, Bangladesh.

Munzur MM, Islam MN, Akhter S, Islam MR (2004). Effect of different levels of vegetable oil for the manufacture of Dahi from skim milk. Asian-Australasian Journal of Animal Science, 17: 1019-1025.

Perdigon G, LBA de Moreno, J Valdez, Rachid M (2002). Role of dahi in the prevention of colon cancer. European Journal of Clinical Nutrition, 56 (Supplementary), 3: 65-68.

Ranganna S (1977). Manual of analysis of fruit and vegetable products. $2^{\text {nd }}$ Edn, Tata MeGraw-Hill Publishing Company, New Delhi, India, P. 634.

Shukla FC, Jain SC, Sandhu KS (1987). Technological and physiological aspects of yoghurt and fruit yoghurt. Indian Journal of Dairy Science, 90: 12-16. 